\section{VIVIENDA SOCIAL Y SEGREGACIÓN ESPACIAL EN LA CIUDAD DE PUCÓN, CHILE: entre el enclaustramiento $y$ la integración con el hábitat turístico ${ }^{1}$}

Hugo Marcelo Zunino

Rodrigo Hidalgo Dattwyler ${ }^{3}$

Esteban Marquardt Zapata ${ }^{4}$

\section{Resumen}

Este trabajo explora las particularidades que adquiere la segregación espacial de la vivienda social en la Ciudad de Pucón, un balneario de elite localizado en el sur de Chile. Una encuesta aplicada al 18\% de las familias residentes en el mayor conjunto de vivienda social construido por el Estado en los últimos años mostró altos niveles de satisfacción residencial, movimientos pendulares frecuentes, y una valoración positiva del entorno natural. Los problemas más agudos que enfrentan los residentes son el desempleo durante la época invernal y la ausencia de equipamiento comunitario. Se observó que los vecinos de dicho conjunto no se involucran en los procedimientos formales de participación ciudadana. Sin embargo, las entrevistas conducidas

\section{SOCIAL HOUSING AND SPATIAL SEGREGATION IN THE CITY OF PUCÓN, CHILE: Between Confinement and Integration with Tourist Habitat $^{1}$}

\author{
Hugo Marcelo Zunino² \\ Rodrigo Hidalgo Dattwyler ${ }^{3}$ \\ Esteban Marquardt Zapata
}

\section{Abstract}

This paper explores the specific features of spatial segregation of social housing in Pucón, an elite tourist destination located in southern Chile. A survey applied to the 18\% of families who inhabit the largest social housing complex ever built in recent years showed high levels of residential satisfaction, frequent commuting movements and a positive evaluation of the natural environment. The most severe problems faced by residents are unemployment during the winter, as well as the lack of urban amenities. Although the neighbors are not engaged in formal participation procedures, interviews conducted with community leaders allowed 
con los dirigentes vecinales permitieron colegir que las organizaciones sociales existentes son capaces de representar al gobierno local los problemas que enfrenta la comunidad y presionar por soluciones. Estos antecedentes sugieren que la construcción de complejos de vivienda social en la cercanía de ciudades y pueblos con vocación turística constituye una opción para redefinir los criterios básicos de localización de viviendas sociales, siempre que tres condiciones sean cumplidas: fuentes laborales estables, organizaciones comunitarias fuertes y facilidad de desplazamiento hacia el epicentro de la vida citadina.

\section{PALABRAS CLAVE: SEGREGACIÓN, VIVIENDA SOCIAL, MOVILIDAD, POLÍTICA SOCIAL.}

Fecha de recepción: 08.09.10

Fecha de aceptación: 21.03.11

1 Este trabajo es un resultado parcial del proyecto FONDECYT 1100588 Desarrollo inmobiliario-turístico en área Villarrica-Pucón, entre los años 1992 y 2010: efectos socio-espaciales y el establecimiento de las relaciones de poder.

2 Chile. Ph.D in Geography and Regional Development, The University of Arizona; Geógrafo Pontificia Universidad Católica de Chile. Académico Universidad de La Frontera, Departamento de Ciencias Sociales.

Correo electrónico: hzunino@ufro.cl

3 Chile. Doctor en geografía humana de la Universidad de Barcelona, geógrafo de la Pontificia Universidad Católica de Chile. Académico del Instituto de Geografía de la Pontificia Universidad Católica de Chile.

Correo electrónico: hidalgo@geo.puc.cl

4 Chile. Licenciado en Educación, profesor de estado en Historia y Geografía de la Universidad de La Frontera.

Correo electrónico: emarquardt@ufro.cl

16 revista invi № 71 / Mayo 2011 / Volumen № 26: 15-55 to infer that existing social organizations are able to represent the local government the problems faced by the community and press for solutions. These elements suggest that the construction of social housing complexes near tourist-oriented cities and towns constitutes an option to redefine the basic criteria for the allocation of social housing provided that three conditions are met: stable employment, strong community organizations and convenient mobility conditions to the core of the city life.

\section{KEYWORDS: SEGREGATION, SOCIAL HOUSING, MOBILITY, SOCIAL POLICY.}

Received: 08.09.10

Accepted: 21.03.11

1 This paper is the partial result of the FONDECYT project 1100588 "Real Estate-Tourist Development in the Villarrica-Pucón Area between 1992 and 2010: Socio-Spatial Effects and Establishment of Power Relationships."

2 Chile. Ph.D. in Geography and Regional Development, The University of Arizona; Geographer, Pontificia Universidad Católica de Chile. Academic, Universidad de la Frontera, Department of Social Sciences.

Email: hzunino@ufro.cl

3 Chile. Ph.D. in Human Geography, Universidad de Barcelona; Geographer, Pontificia Universidad Católica de Chile. Academic, Pontificia Universidad Católica de Chile, Geography Department.

Email: hidalgo@geo.puc.cl

4 Chile. BA in Education, History and Geography Professor. Universidad de la Frontera.

Email: emarquardt@ufro.cl

ARTICLE: Social Housing and Spatial Segregation in the City of Pucón, Chile: Between Confinement and Integration with Tourist Habitat / Hugo Marcelo Zunino, Rodrigo Hidalgo Dattwyler, Esteban Marquardt Zapata 


\section{Pucón: una ciudad cosmopolita y segregada}

La Ciudad de Pucón emplazada en la IX Región de La Araucanía, Chile, constituye un asentamiento turístico y residencial con características únicas. Existen marcadas diferencias entre la época estival y la época invernal, tal como se verifica en la mayor parte de los lugares turísticos del sur de Chile. Durante la época estival la actividad turística domina el quehacer citadino y se expresa mediante tres modalidades no-excluyentes: (a) turismo masivo bajo la modalidad "sol y playa", (b) turismo de "intereses especiales" y (c) turismo de elite centrado en enclaves de recreación y ocio que ofrecen un estándar de servicios similar al encontrado en los centros turísticos más reconocidos a nivel mundial. La actividad turística estival copa la oferta hotelera y crea problemas en la planta urbana, siendo lo más evidente la congestión, la desordenada venta de "paquetes turísticos" y el comercio ambulante. Asimismo, ni al observador menos atento pasa desapercibido el carácter cosmopolita que adquiere el centro de la ciudad, pues en los numerosos cafés y boutiques se entremezclan distintos idiomas y costumbres, dando vida a un ambiente eclético en donde los establecimientos comerciales y otros espacios urbanos frecuentados por los visitantes se convierten en lugares para ser vistos, lugares de exposición. Durante el día, en el epicentro de la ac-

\section{Pucón: A Cosmopolitan and Segregated City}

The City of Pucon, located in the Araucania Region, Chile, is a tourist and residential site with unique features. There are clear differences between winter and summer periods, just as it happens with most tourist sites in southern Chile. During the summer, tourist activity prevails and it has three non-exclusive modalities: (a) massive "sun and beach" tourism; (b) "special interest" tourism; and (c) elite tourism that focuses on recreational and leisure sites that offer services similar to those found on top class tourist centers. During summer, hotels are at full occupancy and there are problems regarding congestion, disorganized sale of "tourist packages" and illegal trade. Additionally, even the most absent minded person would acknowledge the cosmopolitan nature of the downtown. The large number of cafes and boutiques are a melting pot of languages and customs, giving life to an eclectic environment where shops and other urban spaces visited by tourists turn into exhibition places. During the day, in the center of tourist activity, the calm watchfulness of impeccably dressed police officers provides the 
tividad turística, la serena vigilancia de una policía impecablemente uniformada brinda una sensación de seguridad y relajo. En horas de la noche, la ciudad adquiere un ritmo juvenil y desenfrenado. La vigilancia -pública y privada- mantiene bajo control a los jóvenes y son poco frecuentes los altercados con la policía. Así, Pucón constituye una ciudad-fachada, especialmente fabricada para los turistas.

En la época invernal la actividad y la población disminuyen considerablemente, pero la ciudad no pierde su carácter cosmopolita. En efecto, la disminución del ritmo de vida se ve compensada, en parte, por la creciente migración de un contingente poblacional de diversas nacionalidades compuesto de artistas, familias e individuos que buscan parajes naturales para vivir en conexión con la naturaleza o, en algunos casos, buscan un lugar que haga posible replantear su existencia terrenal y desarrollar estilos de vida nuevos y/o alternativos. ${ }^{5}$ Estos nuevos vecinos logran mantener una actividad comercial continua durante el año y una incipiente dinámica cultural que se desarrolla en cafés, centros de eventos y residencias particu-

5 En la literatura tradicional a este migrante se le denomina "migrante de amenidad", que es definido como el individuo que migra en función de las amenidades naturales y culturales en el lugar de destino; estos migrantes son por lo general gente con estudios secundarios completos, en muchos casos con estudios universitarios, y de buena situación económica que les permite residir en lugares en los cuales las ofertas laborales son escasas (Otero, 2006; González et al., 2009).

18 revista invi № 71 / Mayo 2011 / Volumen N ํo 26: 15-55 sense of security and peacefulness. At night, the city takes a young and uncontrolled pace. Public and private security agents keep youngsters under control and there are few problems with the police. In this way, Pucon is a double-faced city especially designed for tourists.

During winter, there is a decrease in activity and population; however, the city does not lose its cosmopolitan nature. In fact, such a decrease is partly compensated by the growing migration of artists, families and individuals from different nationalities who are looking for natural places in order to live connected with nature, or, in some cases, to redefine their existence and develop new and alternative lifestyles ${ }^{5}$. These newcomers contribute to maintain a continuous economic activity throughout the year, as well as an incipient cultural dynamic, which is developed in cafes, events centers and private residences. In Pucón, contrary to what happens in summer, social and cultural life takes place silently during the winter, and those who visit

5 In traditional literature, this person is known as "amenity migrant", which is the individual who migrates according to the natural and cultural amenities of the destination area. These migrants are generally people with completed secondary education, in many cases with a university degree, and have good economic situation, which allows them to stay in places where job opportunities are scarce (Otero, 2006; González et al., 2009)

ARTICLE: Social Housing and Spatial Segregation in the City of Pucón, Chile: Between Confinement and Integration with Tourist Habitat / Hugo Marcelo Zunino, Rodrigo Hidalgo Dattwyler, Esteban Marquardt Zapata 
lares. A diferencia de lo que sucede en Pucón durante la época estival, en el invierno la vida social y cultural se desarrolla en forma silenciosa y a aquél que visita el lugar por primera vez o por cortos periodos le resulta difícil comprender los léxicos locales ${ }^{6}$.

A la par con el incremento de la actividad turística y residencial, los negocios inmobiliarios para usos de primera o segunda residencia se han materializado con fuerza en la comuna. Dicha oferta incluye terrenos para la "construcción por encargo" y unidades terminadas. En la primera modalidad, operan una amplia gama de empresas constructoras, desde aquellas que ofrecen "casas semi-industrializadas" destinadas a familias de poder adquisitivo medio o medio-alto hasta empresas sumamente especializadas en el diseño y construcción de residencias exclusivas de alto valor arquitectónico y monetario. La oferta de unidades terminadas incluye, principalmente, departamentos en la planta urbana y viviendas en condominio en el área rural. Muchas de las empresas son las mismas que llevan adelante grandes emprendimientos en el Área Metropolitana de Santiago, como Fernández Wood con el lujoso proyecto "La Península", el cual ofrece exclusivos servicios y equipamientos como canchas de golf y tenis, senderos para trekking, playas

$6 \quad$ Las consecuencias territoriales y culturales de la migración de amenidad en la Ciudad de Pucón han sido analizadas en Zunino e Hidalgo, 2010 e Hidalgo y Zunino, 2011. the city for the first time, or for brief periods of time, find it difficult to understand local expressions ${ }^{6}$.

Along with the increase in tourist and residential activity, real estate business for residential use has increased as well. This kind of business includes land for "construction on request" and finished units. In the first modality, there is a large number of construction firms, ranging from those that offer "semi-industrialized houses", designed for middle and upper-middle income families, to those highly specialized firms in the field of design and construction that offer exclusive residences of high architectural and monetary value. The supply of finished units includes apartments located in the urban area and condominiums located in the rural area. Many of these firms are developing projects in the Metropolitan Area of Santiago, such as Fernández Wood and its "La Península" project, which offers exclusive services and amenities, including a golf course and a tennis court, trekking routes, private beaches, a spa, a sport-recreational complex and a school. All these residential modalities are open to those

6 Territorial and cultural consequences of amenity migration in Pucón have been analyzed in Zunino e Hidalgo, 2010 and Zunino, 2011. 
privadas, spa, complejo deportivo-recreacional y colegio. Todas estas modalidades residenciales están abiertas para los migrantes que han hecho, en los últimos años, de Pucón su hogar.

Así, por una parte, nos encontramos frente a un paraje idílico donde conviven turistas de elite, una pequeña pero influyente elite intelectual-financiera, migrantes en búsqueda de nuevos estilos de vida y artistas alternativos; por otro lado, en la periferia urbana, alejados del epicentro de la actividad turística, encontramos una serie de complejos de vivienda social segregados y que exhiben carencias materiales evidentes. Si bien el municipio apuesta por convertir a la ciudad en un lugar privilegiado en cuanto a la dotación de infraestructura, equipamiento y composición socio-económica, no puede eludir los problemas sociales que afectan a la población pobre de la comuna que habita en el área rural o en la periferia de la ciudad, en condición de allegados.

La Figura 1 muestra los doce conjuntos de vivienda social edificados entre los años 1972 y 2006 y es indicativo de la tendencia de ubicación periférica que ocupan estos conjuntos.

Aprovechando los menores precios y disponibilidad de suelo vacante, estos conjuntos representan la forma en que el Estado chileno tradicionalmente ha intentado dar solución a la escasez de residencias de los sectores populares del país, contribuyendo a la acumulación de pobres en determina- migrants who have settled in Pucon during the last years.

On the one hand, there is an idyllic site where elite tourists, a small but intellectually and financially influential group, people who are looking for new lifestyles and alternative artists coexist. On the other hand, in the periurban areas, away from the center of the tourist activity, there is a series of segregated social housing that present evident infrastuctural shortfalls. Although the town council is working to turn the city into a privileged place regarding infrastructure, amenities, and socioeconomic composition, it cannot ignore the social problems that affect the poor population who live in the rural and peri-urban area of the city.

The figure 1 shows the 12 social housing complexes built between 1972 and 2006, it indicates the peripheral location trend of these complexes.

By taking advantage of the low prices and the availability of vacant land, these complexes represent the way the Chilean State has tried to solve the shortage of housing in popular areas, concentrating poor people in specific places of the city and generating zones of exclusion

ARTICLE: Social Housing and Spatial Segregation in the City of Pucón, Chile: Between Confinement and Integration with Tourist Habitat / Hugo Marcelo Zunino, Rodrigo Hidalgo Dattwyler, Esteban Marquardt Zapata 
FIGURA 1. LOCALIZACIÓN DE LAS VIVIENDAS SOCIALES CONSTRUIDAS EN PUCÓN, 1972-2006 FIGURE 1. LOCATION OF SOCIAL HOUSING BUILT IN PUCÓN, 1972-2006

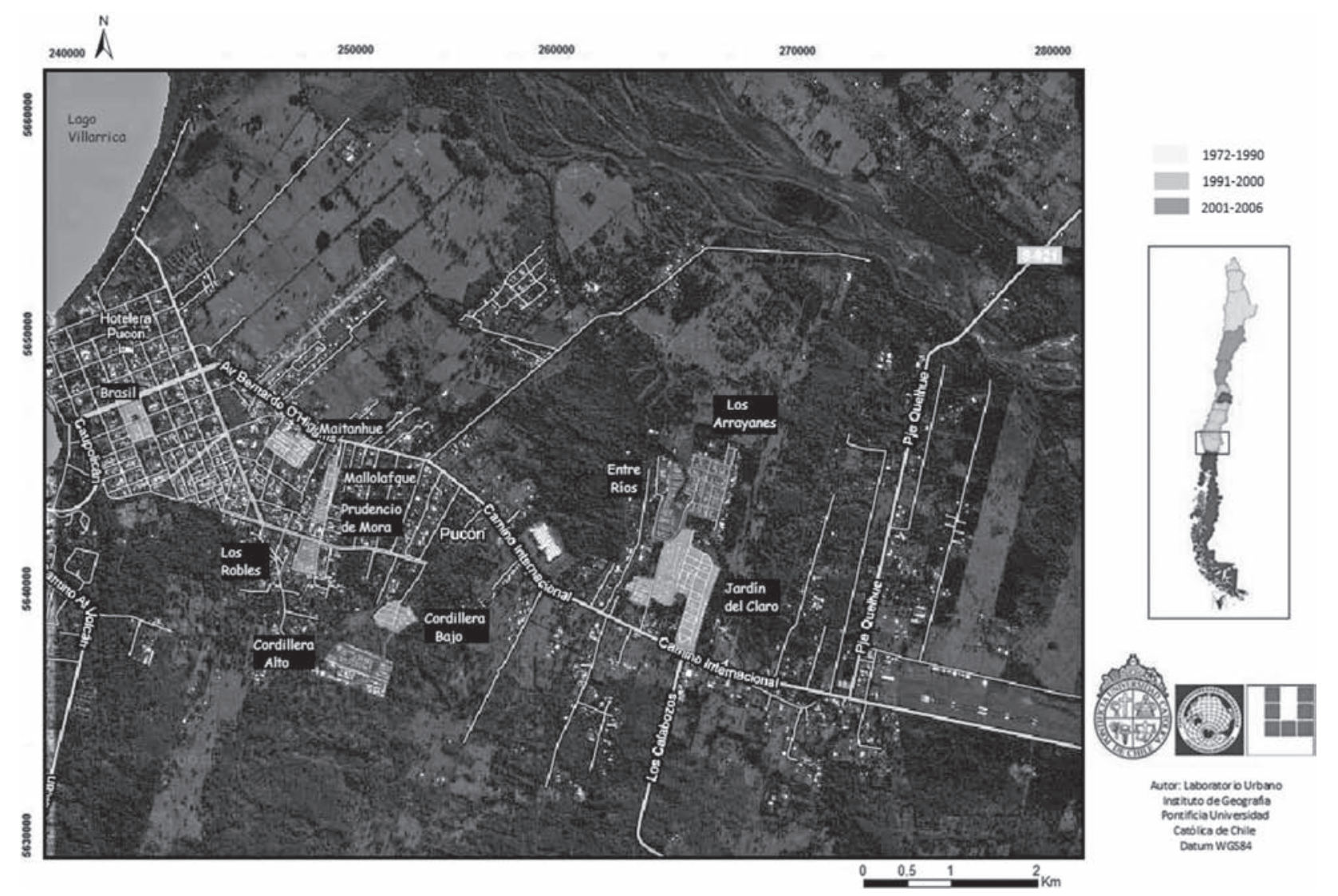

FUENTE: Elaboración propia en base a información obtenida de la Ilustre Municipalidad de Pucón, 2006 y Dirección de Obras Municipales, 2010.

SOURCE: Author's elaboration based on information from the Municipalidad de Pucón, 2006 and Dirección de Obras Municipales, 2010. 
dos lugares de la ciudad y generando una imagen de áreas de exclusión y desigualdad. La vivienda social es todo un símbolo de las ciudades chilenas. Las figuras 1 y 2 muestran que los conjuntos residenciales construidos por el Estado en la comuna se ubican desde la década de 1980 en los límites del casco urbano consolidado. Siguen y en ocasiones conducen el crecimiento de la ciudad y acumulan a la demanda no solvente de vivienda a la cual el Estado debe dar solución. Pero, a diferencia de lo que ocurre en la grandes ciudades, si estos espacios son equipados y servidos adecuadamente en términos de cobertura y servicios, podrían aportar de manera directa al desarrollo de los ejes esenciales que sostienen la vida comunitaria y la producción económica del espacio.

En consecuencia, pese a sus particularidades, la ciudad-balneario lacustre de Pucón no queda al margen de la dinámica espacial y residencial que caracteriza a las ciudades chilenas: departamentos en altura o viviendas en condominio para aquellos que pueden optar a la oferta generada por el mercado y viviendas sociales destinadas a la demanda no solvente. En este contexto, el trabajo que presentamos plantea algunas interrogantes que pretende resolver y que son trascedentes para entender cómo se están llevando a cabo las dinámicas sociales y espaciales que son propias de Pucón en la actualidad y que dicen relación con: ¿Cómo se relacionan funcionalmente los habitan- and inequality. Social housing is a symbol of Chilean cities. The figures 1 and 2 show that, since 1980, residential complexes built by the State have been located in the limits of the town center. These buildings continue to spread and, in some occasions, lead the growth of the city, increasing the non-solvent demand for housing that should be tackled by the State. However, unlike major cities, if these spaces are properly provided with amenities in terms of coverage and services, they could contribute directly to the development of the essential axes that sustain communal life and the economic production of space.

Consequently, in spite of its special characteristics, Pucon is not exempt from the spatial and residential dynamics of Chilean cities: high-rise or condominiums available for those who have access to the supply generated by the market and social housing for the non-solvent demand. How are social housing dwellers functionally related to the town center? Do they feel dissatisfied with living in their current places? Do they regard the relative closeness to better-off areas as an advantage or as a disadvantage? This article puts forth these questions and their solutions, which are essential to understand the way 
FIGURA 2. EXPANSIÓN URBANA EN LA CIUDAD DE PUCÓN, 1983-2007

FIGURE 2. URBAN SPRAWL IN PUCÓN, 1983-2007

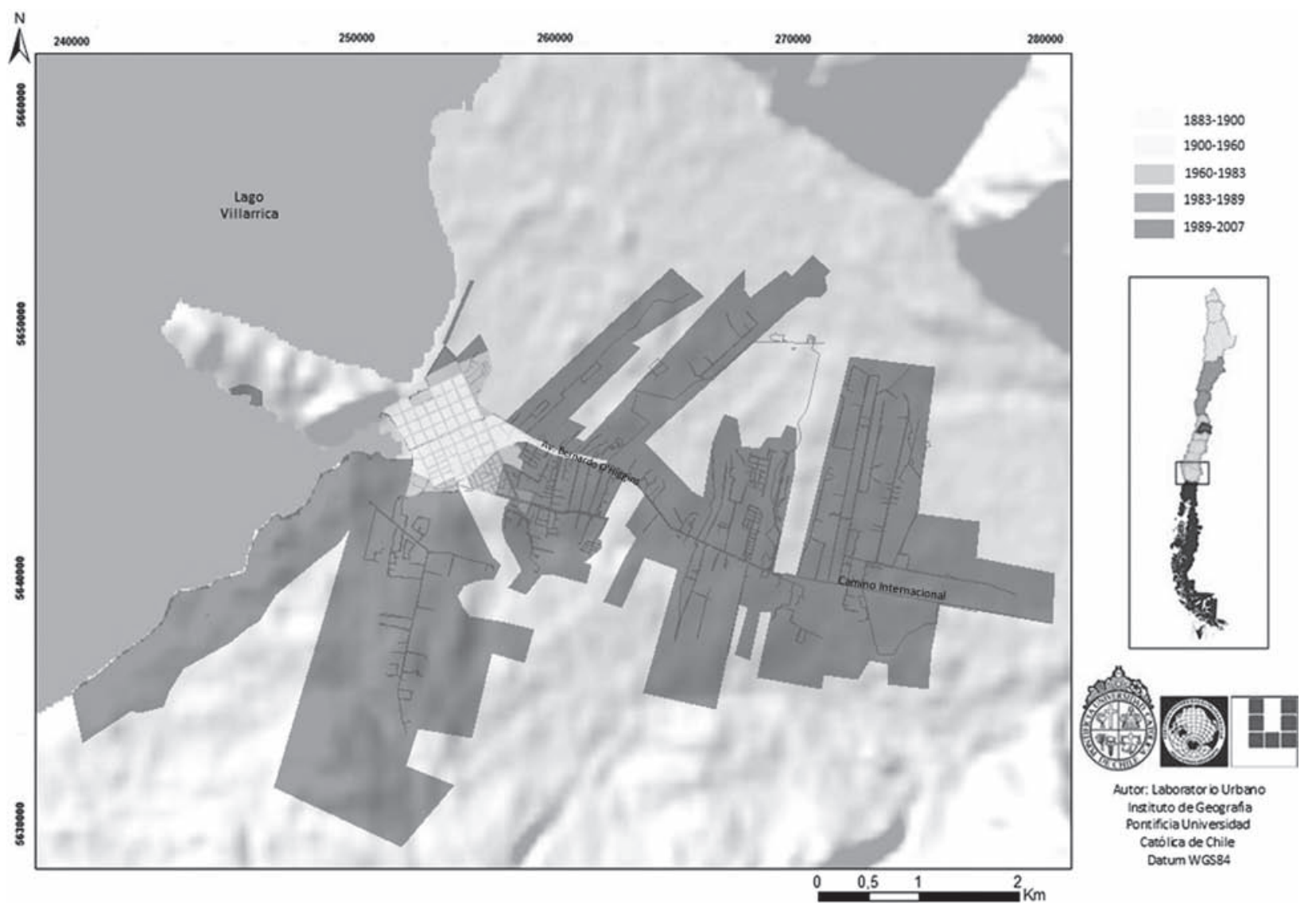

FUENTE: Elaboración propia en base a información contenida en la Ilustre Municipalidad de Pucón, 2006. SOURCE: Author's elaboration based on information from the Municipalidad de Pucón, 2006. 
tes de los complejos de vivienda social con el casco central consolidado? ¿Se sienten satisfechos de residir en el lugar? ¿Perciben la cercanía relativa con los sectores acomodados como una ventaja o una desventaja? Estas son las preguntas que guiaron la investigación.

La particularidad de este trabajo radica en que gran parte de la literatura chilena sobre segregación residencial y efectos territoriales de la política de vivienda se ha centrado en las repercusiones socio-espaciales de los conjuntos localizados en los arrabales de las grandes metrópolis y en la conformación de guetos urbanos ${ }^{7}$, que desembocan, cuando se edifican en la periferia rural, en la denominada "precariópolis estatal". Asimismo, este trabajo presta debida atención al contexto en el cual se desarrolla la dinámica residencial; razón por la cual este trabajo más que proponer soluciones generales replicables en diversas situaciones, apunta a sugerir nuevos lineamientos para asentamientos menores marcados por la actividad turística. Este campo de investigación permanece inexplorado y los resultados obtenidos ofrecen directrices sobre cómo reorientar la política de vivienda social en pueblos y ciudades chilenas que

7 Brain y Sabatini, 2006; Brain et al., 2007; Rodríguez y Sugranyes, 2004; Rodríguez y Sugranyes, 2005.

8 Hidalgo, 2007.

24 revista invi № 71 / Mayo 2011 / Volumen № 26: 15-55 social and spatial dynamics are being carried out in Pucón.

The special feature of this research lies in the fact that most of Chilean literature on residential segregation and the territorial effects of housing policies is focused on both the socio-spatial consequences of the complexes built in the poor areas of large metropolises, and the formation of urban ghettos ${ }^{7}$, which, when located in the peri-urban area, generate the so-called "State-precariópolis" ${ }^{8 "}$. Likewise, this article analyzes the context in which residential dynamics takes place; hence, this research, instead of proposing general solutions that may be replicated in different situations, suggests new guidelines for minor settlements that depend on tourist activity. This field of research is still unexplored and the results obtained offer guidance for redirecting social housing policies in Chilean towns and cities that have grown in population as a result of the increase in migration and tourist activity. This is the case of San Pedro de Atacama, Villarrica,

7 Brain and Sabatini, 2006; Brain et al., 2007; Rodríguez and Sugranyes, 2004; Rodríguez and Sugranyes, 2005.

8 Portmanteau of the words "precarious" and "metropolis". Translator's note. Hidalgo, 2007. 
han visto incrementar su contingente poblacional como consecuencia del aumento de la actividad turística y migración. Tal es el caso de ciudades chilenas como San Pedro de Atacama, Villarrica, Frutillar y Puerto Varas, entre otras. ${ }^{9}$ Para enfatizar: el argumento subyacente en esta investigación es que se debe prestar debida atención al contexto socio-espacial, cultural y económico para que las intervenciones en materia de vivienda social sean eficientes en términos de una mejor calidad de vida para los sectores más pobres.

En este contexto, tomamos como caso de estudio el conjunto de vivienda social "Cordillera Alto", construido entre los años 2001 y 2003 y situado en los límites de la zona urbana, alejado del epicentro de la actividad turística, oculto para el turista estacional (Figura 1). Este complejo residencial puede considerase una "heterotopía"10, un espacio que escapa a lo perceptible y que resulta "extraño" al contexto urbano circundante. Su construcción fue inducida tanto por factores políticos como por las necesida-

9 Los autores están trabajando actualmente en examinar detalladamente las consecuencias socio-espaciales de la política de vivienda social aplicadas en distintas ciudades-balnearios localizadas en diversas regiones de Chile. Los primeros resultados se esperan para el año 2012

10 El término "heteropía" fue acuñado por Michel Foucault (1986) para referirse a un espacio singular que, estando débilmente relacionado con el territorio circundante, permanece en un estado y situación no-hegemónica y ajena al contexto espacial circundante. Ejemplos incluyen cárceles, hospitales y centros ceremoniales.
Frutillar and Puerto Varas, among others ${ }^{9}$. To emphasize: the underlying argument of this research is that the socio-spatial cultural and economic context should be taken into special account, so that optimizing social housing interventions and thus improving the quality of life in deprived areas.

In this context, the social housing complex "Cordillera Alto" has been chosen as case study. This complex was built between 2001 and 2003 and it is located in the limits of the urban area, away from the center of the tourist activity; it is hidden for the common tourist. See figure 1. "Cordillera Alto" may be regarded as a "heterotopia"10, that is to say, a space that escapes from perceptibility, resulting in a "strange" zone when contrasted with the surrounding urban context. Political factors and the needs for rural population to

9 Authors are currently working on the socio-spatial consequences of social housing policies in different tourist sites located in different regions of Chile. The first results are expected in 2012.

10 The term "heterotopia" was coined by Michel Foucault (1986) to refer to a singular space that is weakly related to the immediate territory and remains in a non-hegemonic state and situation; it is a space outside the spatial surrounding context. Prisons, hospitals and ceremonial centers are examples of heterotopias. 
des de la población rural de la comuna de acceder a modos de vida más modernos y superar, en parte, las condiciones de vida de sus lugares de origen.

Cordillera Alto se inserta dentro del "Programa de Vivienda Progresiva", el cual apunta a entregar una unidad habitacional básica, no una vivienda terminada. Bajo dicho programa, el estado entrega una vivienda con estándares mínimos de habitabilidad (baño, cocina y un dormitorio). El diseño permite que este hábitat residencial sea posteriormente intervenido para ampliar y separar los distintos espacios. La población Cordillera Alto se localiza en el límite sur poniente del área urbana de Pucón, este conjunto de viviendas representa casi un 30\% de las casi mil viviendas sociales construidas en la historia de Pucón (Tabla 1)

El programa de vivienda progresiva de la población Cordillera Alto contempló residencias con una superficie aproximada de $28 \mathrm{~m}^{2}$ e incluyó en su diseño baño, cocina y estar-comedor. Las etapas siguientes fueron proyectadas para la ampliación de los dormitorios de la residencia. La edificación de este complejo se materializó vía una iniciativa conjunta entre el Ministerio de Vivienda y Urbanismo y la Ilustre Municipalidad de Pucón. La organización de la comunidad en los Comités de Vivienda fue fundamental para llevar a cabo la iniciativa, a cada familia se le exigió un ahorro previo de 250.000 pesos chilenos (U\$ 510). Aproxima- have access to modern lifestyles gave birth to "Cordillera Alto".

This complex is part of the "Progressive Housing Program", which aims at providing basic housing units, not a finished house. Under this program, the State provides housing with basic habitability standards (a bathroom, a kitchen and a bedroom). The design of these houses allows further interventions so as to expand and separate the different spaces. "Cordillera Alto" is located in the south-west limit of the urban area of Pucón, this complex represents $30 \%$ of the 1,000 social housing built in Pucón. See Table 1.

The Progressive Housing Program for "Cordillera Alto" considered $28 \mathrm{~m} 2$ housing and included a bathroom, a kitchen and a diningliving room; the following phases planned for the expansion of the bedroom. The construction of this complex was jointly carried out by the Ministry of Housing and Urban Development and the Municipality of Pucón. The Housing Committee, a community organization, was essential for the materialization of this project. Each family was required to have $\$ 250,000$ 
TABLA 1. POBLACIONES DE VIVIENDA SOCIAL CONSTRUIDAS EN LA COMUNA DE PUCÓN, 1972-2006 TABLE 1. SOCIAL HOUSING COMPLEXES BUILT IN PUCÓN, 1972-2006

\begin{tabular}{llll} 
Población & Año de recepción & Número de viviendas & Porcentaje \\
\hline Brasil & 1972 & 41 & 3,84 \\
\hline El Convento & 1979 & 18 & 1,68 \\
\hline Maitanhue & 1988 & 40 & 3,74 \\
\hline Jardines del Claro & 1990 & 40 & 3,74 \\
\hline Prudencio Mora & 1992 & 80 & 7,48 \\
\hline Mallolafquén & 1992 & 80 & 7,48 \\
\hline Cordillera Bajo & 1996 & 168 & 15,72 \\
\hline Los Robles & 1996 & 33 & 3,09 \\
\hline Bomberos de Chile & 2000 & 140 & 13,10 \\
\hline Los Arrayanes & 2001 & 78 & 7,30 \\
\hline Cordillera Alto & 2003 & 291 & 27,22 \\
\hline Entre Ríos & 2006 & 60 & 5,61 \\
\hline Total & & 1069 & 100,00
\end{tabular}

FUENTE: Dirección de Obras Municipales, 2009.

SOURCE: Dirección de Obras Públicas, 2009.

damente el 50\% de los beneficiados provienen del área rural de la Comuna de Pucón ${ }^{11}$.

El resto del trabajo se organiza como sigue. En el siguiente aparatado explicaremos la metodología utilizada y su finalidad. En el tercer apartado examinaremos recientes aportes de la literatura sobre

11 En base a datos contenidos en el registro de la Dirección de Obras Municipales, 2010.
(US\$510) saving. About 50\% of beneficiaries came from rural areas of Pucón ${ }^{11}$.

In the following section, the methodology used for this research, and its purpose, is explained. The third part of this article analyzes recent

11 Based on information from the Department of Public Works, 2010. 
los efectos sociales y espaciales de la segregación residencial y enfatizaremos en la noción de satisfacción residencial, la cual tiene larga tradición en los estudios habitacionales desde la mitad del Siglo XX. En el cuarto apartado analizaremos los resultados de las encuestas y entrevistas aplicadas. Tomando debida consideración al particular contexto de la Ciudad de Pucón, en la sección final examinaremos los factores que son críticos para intervenir eficazmente en materia de vivienda social en asentamientos menores con una vocación turística marcada.

\section{Metodología}

Para conocer el grado de integración de los pobladores del complejo de vivienda social Cordillera Alto con el resto de la ciudad y su satisfacción con la vivienda y el entorno, en junio de 2010 se realizó una encuesta dirigida a los jefes de hogar de dicho conjunto de viviendas. La muestra abarcó al 18.5\% de las familias residentes en el lugar (291 familias). La encuesta, en lo medular, consideró aspectos como: (a) nivel educacional, (b) oficio, (c) integrantes del grupo familiar, (d) satisfacción con la vivienda y el barrio y (e) movilidad diaria de los pobladores para satisfacer sus necesidades básicas (por ejemplo: empleo, alimento y educación). literature contributions to the field of social and spatial effects of residential segregation. Likewise, the notion of residential satisfaction is studied; this concept has a long tradition in housing studies since the second half of the XXth century. The fourth section of this work analyzes the surveys and interviews results. The final section of this article, taking into consideration the particular context of Pucón, examines the critical factors for an effective social housing intervention in minor touristoriented settlements.

\section{Methodology}

In June 2010, the heads of households of "Cordillera Alto" were surveyed so as to know their level of integration in relation to the rest of the city, as well as their level of satisfaction with their housing and environment. This exercise surveyed the $18.5 \%$ of total households (291). Basically, this poll considered aspects such as: (a) level of education, (b) occupation, (c) family members, (d) satisfaction with the housing units and neighborhood, (e) daily mobility of dwellers in order to meet their basic needs (job, food and education). 
Un punto central de la encuesta fue examinar el grado de satisfacción residencial. Para ello se utilizó una escala del 1 al 10, siendo 10 el valor de máxima satisfacción. Esta forma de estimar la satisfacción residencial se conoce como "Escala de Cantril"12. A pesar que esta técnica ha sido blanco de variadas críticas relacionadas, por ejemplo, con la subjetividad con que los informantes responden las interrogantes planteadas ${ }^{13}$; a nuestro entender permite capturar la percepción espontánea de un contingente poblacional relativamente homogéneo. Tomando en cuenta dicha limitación, esta escala ha sido utilizada en Chile por Figueroa y Larraín (1989) e Hidalgo y Zunino (1992) para evaluar la satisfacción en sectores centrales de la ciudad de Santiago, obteniéndose resultados coherentes con los supuestos iniciales planteados por los investigadores. Así, si bien la Escala de Cantril no constituye un indicador sofisticado, tiene la virtud de acceder a una visión general sobre las condiciones de vida que enfrenta una población que comparte similares características sociales y culturales, y mantiene un discurso y un entendimiento del mundo similar.

La encuesta fue tabulada en una matriz de doble entrada. Se trabajó con indicadores estadísticos simples para interpretar la muestra. Para validar las inferencias de los investigadores y para explicar situaciones no contempladas, las respuestas fueron

12 Cantril, 1965.

13 Ver Díez y Torregrosa, 1967.
The main aim of this survey was to identify the level of residential satisfaction. To do so, a scale from 1 to 10 was used, with 10 being the highest satisfaction. This method is known as the "Cantril Scale"12. Even though this measurement pattern has been criticized because of the subjective answers that people provide ${ }^{13}$, it allows for capturing spontaneous perception of a homogeneous group. By taking such a restriction into consideration, this scale has been used in Chile by Figueroa and Larrain (1989) and Hidalgo and Zunino (1992) to assess satisfaction in central areas of Santiago. The results of the survey were in line with the initial hypothesis put forth by the researchers. In this way, while the Cantril Scale is not a sophisticated indicator, it provides a general overview of the life conditions of people who share cultural and social characteristics and have the same perception of the world.

This survey was tabulated in a double entry matrix and simple statistical indicators were used to interpret the results of the analysis. In order to validate the inferences of the researchers to explain situations which were not considered in the study, the results of this

12 Cantril, 1965.

13 See Díez and Torregrosa, 1967. 
cotejadas con la visión de 5 dirigentes vecinales vía entrevistas dirigidas a examinar y discutir los resultados derivados de la encuesta. Las entrevistas y la encuesta aplicada constituyen la forma en que generamos la evidencia que sustenta nuestros resultados. Ambos métodos se complementan en el sentido que las entrevistas fueron aplicadas a-posteriori de la tabulación e interpretación inicial de la muestra y fueron dirigidas - ex profeso- a aspectos en los cuales no se tenía claridad sobre cómo interpretar los resultados de la encuesta o se contraponían a las preconcepciones de los investigadores.

Así, este trabajo combina un instrumento de tipo cuantitativo (encuesta) apoyado por una aproximación cualitativa-interpretativa. Cabe precisar que esta investigación no pretende alcanzar un conocimiento científico desinteresado, como un enfoque tradicional positivista aspiraría a alcanzar. Estamos conscientes que no podemos escapar de nuestra subjetividad al analizar una realidad socialmente construida en base a una evidencia externa; no por ello renunciamos a alcanzar conclusiones válidas, en el sentido que sin ser generalizables (replicables en distintos escenarios) son aplicables en el contexto en que estamos trabajando y potencialmente extrapolables a situaciones similares. survey were compared with the opinion of five community leaders, through interviews, so as to examine and discuss the findings of this exercise. The survey and interviews generated the evidence that supports the results of this research. These methods are complementary, as the interviews were conducted after the tabulation and interpretation of survey results. Such interviews were used to define some results that were difficult to interpret and to clarify conflicts between some aspects of the survey and researchers' preconceptions.

In this way, this article combines a quantitative instrument (the survey) and a qualitativeinterpretative approach. It is worth mentioning that, unlike positivist traditional approaches; this research does not intend to reach a disinterested scientific knowledge. It is clear that it is impossible to avoid subjectivity when a reality that is socially built from external evidence is analyzed. Although the conclusions of this article are not general, they can be applied in the context of this work and may be extrapolated to similar situations. 


\section{Efectos socio-territoriales de la segregación residencial en Chile}

Entenderemos la segregación residencial como la tendencia a la organización del espacio en zonas de fuerte homogeneidad social interna y de fuerte disparidad social, que implica para los individuos una desigual distribución de las oportunidades y beneficios que ofrece la sociedad contemporánea ${ }^{14}$. La segregación residencial ha sido asociada a fenómenos socio-territoriales negativos, como la formación de enclaves de pobreza, delincuencia y falta de oportunidades.

En Chile, los estudios sobre segregación han centrado, en su mayor parte, la atención analítica en Santiago, capital de Chile. Para De Mattos (1999, 2002, 2010), los procesos de reestructuración y globalización han provocado la persistencia de una estructura social metropolitana polarizada y segregada, en la que se ha acentuado la tendencia a que los pobres vivan junto a los pobres y los ricos junto a los ricos. Estas transformaciones pueden ser interpretadas como la culminación de ciertas tendencias y fenómenos inherentes al proceso de construcción urbana capitalista. En los últimos años, uno de los efectos de la liberalización económica y desregulación fue despejar el camino para

14 Castells, 1996; Linares y Lan, 2007.

\section{Socio-Territorial Effects of Residential Segregation in Chile}

Residential segregation is the trend to spatial organization in zones with strong inner homogeneity and large social disparity. This situation means an unequal distribution of opportunities and benefits offered by contemporary society ${ }^{14}$. Residential segregation has been associated with negative socioterritorial effects, such as the generation of zones that concentrate poverty, crime and deprivation of opportunities.

In Chile, studies about segregation are mostly focused on Santiago, the capital of the country. According to De Mattos (1999, 2002, 2010), restructuration processes and globalization have consolidated a polarized and segregated metropolitan social structure. This fact has increased the trend to concentrate poor people and rich people in separated areas. Such transformations can be interpreted as the culmination of trends and phenomena that are specific to the process of capitalist urban construction. During the last years, one of

14 Castells, 1996; Linares and Lan, 2007. 
la afirmación de una lógica estrictamente capitalista en la producción y la reproducción metropolitana. Para el mismo autor (2010), la apertura económica iniciada a mediados de los 1970s desplazó gradualmente a las propuestas del urbanismo y la planificación urbana normativa y racionalista, consolidando la lógica estrictamente capitalista en el desarrollo metropolitano que en Chile adquirió hegemonía indisputable a partir del inicio de la década de los 1980s.

Diversos estudios desarrollados en Chile, entre los que se puede citar a Brain et al. (2007), Brain y Sabatini (2006) y Rodríguez y Sugranyes (2004, 2005), muestran no tan sólo que la segregación social ha aumentado en los últimos 30 años por vía de la construcción de extensos barrios de viviendas sociales para los más pobres ubicados en la periferia de las ciudades chilenas, sino que también enfatizan la formación de extensos guetos urbanos caracterizados por ausencia de equipamientos cercanos al lugar de residencia, lo cual impide que los residentes satisfagan las necesidades complementarias a la habitación. Para estos investigadores, esta situación está incrementando la intensidad y el grado de desesperanza de la población beneficiaria de la política de vivienda, cuyos integrantes enfrentan diversas patologías sociales como crímenes, tráfico de drogas, deserción escolar e inseguridad, entre otras. En similar línea argumentativa, Arriagada (2000) enfatiza que aquellos individuos excluidos socialmente tienden a reproducir la po- the effects of economic liberalization and deregulation was the emergence of a capitalist logic regarding metropolitan production and reproduction. As stated by the same author (2010), the economic openness that took place in the mid 70s displaced urban proposals, as well as fationalist and normative urban planning, consolidating a strictly capitalist logic in metropolitan development. Such logic took a dominant role in the early 80s.

A series of studies carried out in Chile, such as Brain et al. (2007), Brain and Sabatini (2006) and Rodríguez and Sugranyes (2004, 2005), show that, apart from the fact that social segregation has increased during the last 30 years-aphenomenon caused by the construction of large social housing neighborhoods located in the peri-urban areas of Chilean cities-, vast urban ghettos have emerged characterized by the absence of amenities, preventing people from satisfying needs different from that of the house. For researchers, this fact has increased the intensity and the level of despair of those benefited from social housing programs. As a consequence, these urban dwellers have to face social pathologies such as crime, drug trafficking, elevatedschool drop-out rate, 
breza, cayendo en un círculo vicioso en que la pobreza genera más pobreza. Si a ello agregamos que la localización otorga ventajas comparativas en el entendido que si los más necesitados viven en lugares bien servidos y equipados, su calidad de vida mejora y en contrapartida cuando esta situación acontece en espacios cada vez más distantes de los beneficios de la centralidad, estamos frente a lo que se ha denominado como la "precariópolis estatal", definida por los precarios servicios de urbanización como, agua potable y luz eléctrica. "En estos lugares, la población habita en residencias con tamaños cuyo promedio no supera los 45 $\mathrm{m}^{2}$ edificados, con ausencia del resto de clases sociales, equipamientos y algunos servicios básicos y no básicos, como colegios, centros de salud, áreas de esparcimiento y centros de comercio, entre otros"15.

La situación expuesta refleja lo que ocurre en las grandes ciudades del país y corresponden a constataciones observadas principalmente en la ciudad de Santiago de Chile. En la última década se han intensificado los esfuerzos para estudiar la segregación residencial en ciudades chilenas intermedias, generalmente capitales regionales o provinciales. Tal es el caso de las investigaciones conducidas por Azocar et al. (2008), Díaz (2005), Garín et al. (2009), Toledo et al. (2000), entre otras de singular valor. Estos estudios tienden a replicar la forma de

15 Hidalgo, 2007, p. 72. and insecurity, among others. In this line, Arriagada (2000) points out that those socially excluded tend to reproduce poverty, falling into a vicious circle in which poverty generates more poverty. Regarding the advantages that localization gives, if people in need live in places with proper amenities, then their quality of life would improve; however, when there is a long distance between urban dwellers and the services provided by centrality, there is a problem of "State-precariópolis". This issue is characterized by the precariousness of urban services (electricity and drinking water). In these places, people live in housing units smaller than $45 \mathrm{~m} 2$ of gross floor area and away from other social groups, amenities and basic and non-basic services, such as schools, health centers, recreational areas, trade centers, among others. ${ }^{15}$

This situation is a reflection of what occurs in major Chilean cities and corresponds to findings observed in Santiago. During the last decade, there has been an increase in the efforts to study social segregation in intermediate Chilean cities, which are generally regional or provincial capitals. This is the case of research carried out by Azocar et al. (2008),

15 Hidalgo, 2007, p. 72. 
abordar el tema de la segregación residencial en las grandes áreas metropolitanas, arribando a similares conclusiones. Tal es el caso de las políticas de viviendas, que son consignadas como uno de los principales inductores de la segregación residencial.

Es en este contexto en el cual nos interesa reducir la escala de análisis desde la metropolitana, regional o provincial a la escala de "ciudad menor" (una ciudad que puede estar entre los 15.000 y 30.000 habitantes). Nos interesa examinar la particularidad o especificidad geográfica más que alcanzar grandes generalizaciones, dadas las características sociales, económicas, demográficas y culturales de la ciudad-balneario de Pucón. Con una población de 21.107 habitantes en el año 2002 (INE, 2002), este caso nos ofrece una oportunidad para estudiar lo singular, lo diferente, lo no-explorado. Reconocemos en toda su magnitud la incidencia de los factores estructurales presentes, una de cuyas manifestaciones es la política de vivienda social impulsada por el Estado y que tiene consecuencias socio-territoriales en distintas escalas geográficas. Pucón no es una excepción y aceptamos desde ya que la liberalización económica, en general, y del mercado del suelo, en particular, son los factores que explican la configuración territorial. La localización de la población "Cordillera Alto" en la periferia urbana, cerca de los usos no deseados como los micro-basurales, por ejemplo, y alejada del epicentro de la actividad turística y cultural, consti-
Díaz (2005), Garín et al. (2009), and Toledo et al. (2000), among other, are important contributions. These studies tend to replicate the way residential segregation is addressed in major metropolitan areas, reaching the same conclusions. This is the case of housing policies, which are regarded as one of the main causes of residential segregation.

In this context, in which the scale of the analysis is reduced from a metropolitan, regional or provincial one to that of a "minor city" (a city with 15,000-30,000 inhabitants), this article focuses more on analyzing geographical features than on providing general information. Given the social, economic, demographic and cultural characteristics of Pucón (21,107 inhabitants in 2002 [INE, 2002]), this case offers the possibility to study singularities, as well as different and unexplored topics. There is a clear awareness of the effects of structural factors, for which social housing policies promoted by the State are one of its expressions. These policies have socio-territorial consequences on different geographic scales. Pucón is not an exemption, this article acknowledges economic liberalization, in general, and land market, in particular, as the factors that define territorial configuration. The localization of "Cordillera 
tuye un factor que reduce el valor del suelo y hace rentable el negocio de la vivienda social. Más aun, la condición de Pucón como balneario de elite, refuerza la operatoria discriminante del mercado, tanto así que la población "Alto Cordillera" no es parte de la ciudad, en el sentido de la continuidad y conectividad geográfica. Una pregunta que surge es si dicha población está emplazada en estricto rigor en un área periférica o bien constituye un núcleo urbano encerrado o enclaustrado. Las fotos 1 y 2 muestran el acceso de la población "Cordillera Alto" y expresan su precariedad, esto es, un camino con carpeta sin cobertura pavimentada, que impide una accesibilidad peatonal adecuada, sobre todo en los meses de invierno.

En estas condiciones objetivas, la noción de satisfacción residencial es compleja y difícil de trabajar cuantitativamente. Por una parte, la idea de "satisfacción" evoca un sinnúmero de variables que dependen de las convicciones, apreciaciones e incluso emociones del sujeto. Por otra parte, no se puede negar una dimensión concreta relacionada con variables como las condiciones de habitabilidad, seguridad del entorno y con una adecuada dotación de la infraestructura y equipamiento urbano. Para De la Puente et al. (1990), la satisfacción se vincula con un sentimiento de agrado o desagrado que experimenta una persona frente a alguna situación e implica componentes cognitivos, emocionales y tendencias de acción. En similar línea argumentativa, Rojo et al. (2001) relacionan, correctamente
Alto" in the peri-urban area, close to undesired uses, such as micro-garbage dumps, and away from the center of tourist and cultural activity, is an element that reduces land value and turns social housing business into a profitable activity. In addition, the status of Pucón as an elite destination, increases market discrimination to the point that "Cordillera Alto", regarding geographic continuity and connectivity, is not part of the city. One of the questions that arises is whether "Cordillera Alto" is effectively located in a peri-urban area, or is an isolated urban space. Pictures 1 and 2 show the precarious access to "Cordillera Alto". It is an unsurfaced road that makes pedestrian access difficult, especially in winter.

Under these conditions, the notion of satisfaction is complex and difficult to measure, quantitatively speaking. On the one hand, "satisfaction" involves a series of variables that depend on people's convictions, interpretations, and emotions. On the other hand, there is a concrete dimension related to variables such as habitability conditions, security and proper distribution of urban infrastructure and amenities. According to De la Puente et al. (1990), satisfaction is linked with a sense of pleasure or displeasure that a 
FOTOS 1 y 2: VÍA DE ACCESO Y VIVIENDAS DE LA POBLACIÓN “CORDILLERA ALTO" PICTURES 1 AND 2. ACCESS AND HOUSES OF "CORDILLERA ALTO"

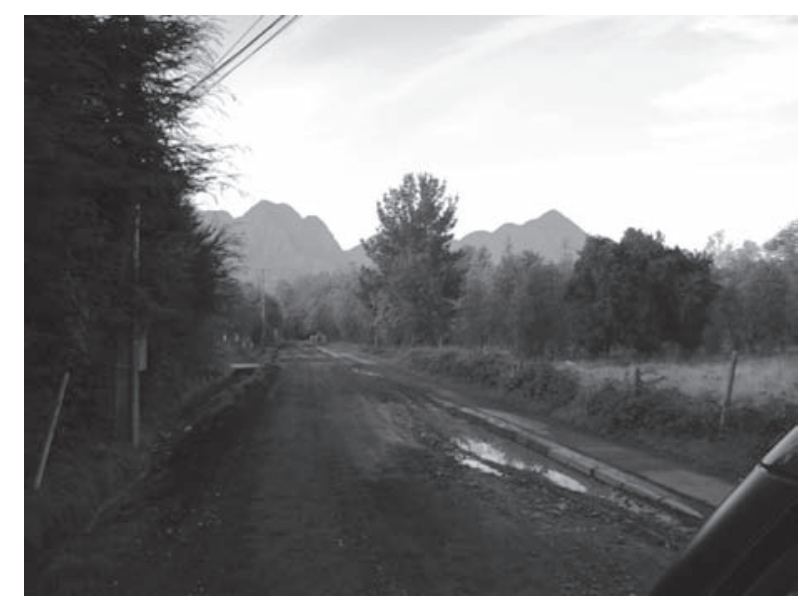

FUENTE: Colección de los autores, abril de 2009. SOURCE: Authors' collection, April 2009.

a nuestro juicio, la satisfacción residencial con la noción de calidad de vida, concepto que también contiene una dimensión subjetiva y una objetiva. Para estos autores, la residencia es el símbolo de la calidad de vida material e inmaterial pues constituye el lugar en donde se satisfacen las necesidades más inmediatas, teniendo efectos sobre la salud mental y física. Consistente con lo anterior, para Amérigo (1995) la satisfacción residencial es un indicador social de carácter subjetivo que captura la relación de conformidad del sujeto con su entorno más inmediato: la vivienda y el barrio. Aparte de

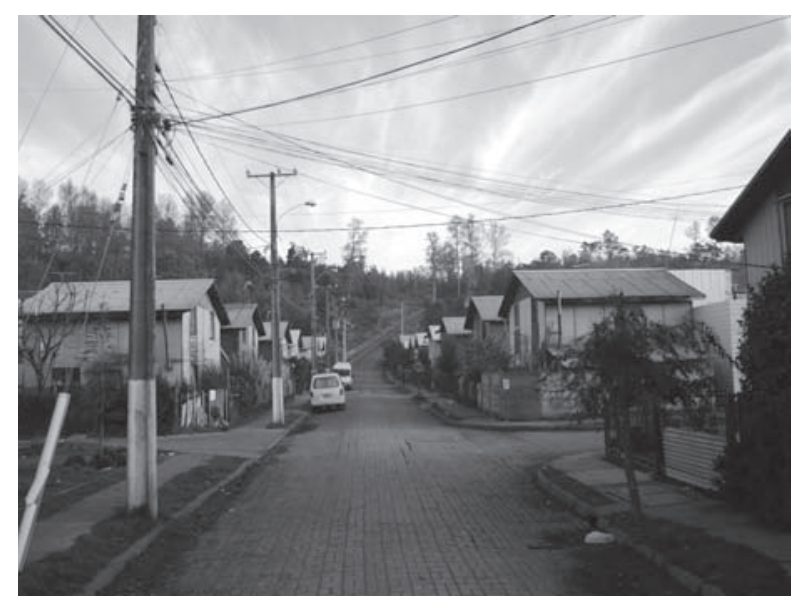

person experiences when facing a determined situation; it includes cognitive and emotional elements, as well as action trends. Likewise, Rojo et al. (2001), links residential satisfaction with quality of life, a concept that has subjective and objective dimensions. For these authors, the place of residence is the symbol of tangible and intangible quality of life, as the place where immediate needs are met, affecting mental and physical health. In line with this description, Amérigo (1995) states that residential

ARTICLE: Social Housing and Spatial Segregation in the City of Pucón, Chile: Between Confinement and Integration with Tourist Habitat / Hugo Marcelo Zunino, Rodrigo Hidalgo Dattwyler, Esteban Marquardt Zapata 
las condiciones materiales, las variables que determinan la satisfacción residencial giran en torno a las aspiraciones que desea cumplir el sujeto y que están condicionadas por el grupo social al que pertenece y que se transforman a lo largo de su ciclo vital. Para el caso de los sectores de bajos ingresos, la satisfacción residencial está más vinculada con las relaciones que mantienen con el barrio y no tanto por la calidad de la residencia: un entorno agradable, relaciones sociales estables y un medio natural privilegiado pueden convertirse en atributos más importantes que los aspectos físicos de la vivienda.

La residencia define cómo el individuo se relaciona con su entorno y compone el núcleo donde se desarrollan las amistades, las relaciones íntimas, y se cultiva el ocio. Asimismo, las características de la residencia y del entorno que ésta ocupa constituyen un factor estratégico para desarrollar vínculos comunitarios y relaciones de reciprocidad que ayudan a conformar lo que Putnam (1983) denominó capital social. Este es un elemento estratégico para la acción colectiva y para la defensa de los interesas comunes. La satisfacción residencial, entonces, resulta de un balance entre las necesidades objetivas y subjetivas de la población y la evaluación personal del grado en que esas necesidades son satisfechas. Así, en la literatura especializada no existe acuerdo sobre las variables que pueden ser utilizadas para estimar la satisfacción residencial. Con todo, diversos autores recalcan la satisfaction is a subjective social indicator that captures the relation of conformity of an individual with his immediate environment, that is to say, the house and the neighborhood. Material conditions apart, the variables that determine residential satisfaction are built around individual's aspirations; these desires, which change over time, are conditioned by the social group this person belongs to. For low income groups, residential satisfaction is mostly linked with the relation they have with their neighborhood, and to a lesser degree, with the quality of the residence. Therefore, aspects such as a pleasant environment, stable social relations and a privileged natural space may transcend the importance of the physical elements of the house.

The place of residence defines how the individual relates with his environment and it is the central space where friendship, intimate relations and leisure activities take place. In addition, the space, and characteristics, of the place of residence are a strategic factor to develop communal links and relations that are useful to give shape to what Putnam (1983) defined as social capital. Social capital is a strategic element for collective action and defense of common interests. Then, residential 
relevancia de aspectos relacionados con la localización de la vivienda y las posibilidades que les ofrece el entorno para satisfacer sus necesidades más inmediatas ${ }^{16}$. Si bien resulta infructuoso tratar de escapar de la subjetividad del informante para estimar el grado de satisfacción, se pueden utilizar técnicas estandarizadas para interpretar los niveles de satisfacción residencial. Tal como se señala en la sección anterior, en esta investigación utilizamos la Escala de Cantril para estimar esta dimensión, en conjunto con una serie de variables que explican los niveles de satisfacción encontrados. Reconociendo el carácter necesariamente limitado de este indicador, para interpretar los niveles de satisfacción se condujeron unas 5 entrevistas con informantes claves de la comunidad; esto es, individuos con reconocimiento colectivo y con la capacidad para hablar en nombre de los vecinos ante las autoridades locales.

En lo que resta del artículo nos centraremos en entender cómo vive esta población, cómo se relaciona con el medio, cuál es su nivel de satisfacción residencial. En un primer análisis los investigadores esperaban encontrar variados efectos negativos asociados con la localización del conjunto residencial Cordillera Alto, lo cual se vería reflejado en bajos niveles de satisfacción residencial, droga-

16 Ver Hidalgo y Zunino, 1992; Figueroa y Larraín, 1989, Toro et al., 2003. satisfaction is the result of a balance between the objective and subjective needs of population and the personal evaluation of the way those needs are met. In specialized literature, there is no agreement on what variables should be used to measure residential satisfaction. Several authors highlight the importance of aspects related to the localization of the house and the possibilities the environment gives to meet immediate needs ${ }^{16}$. Although it is impossible to avoid subjective answers when measuring the level of satisfaction, standardized methods can be used to interpret the levels of residential satisfaction. In order to estimate this dimension, this research used the Cantril Scale, along a series of variables that explain the different satisfaction levels measured. Taking the limited nature of this indicator into account, five interviews with five community leaders were conducted to interpret the different levels of satisfaction.

The rest of this article addresses how these urban dwellers live, the way they relate with their environment and their level of residential satisfaction. In the first analysis, researchers expected to find a series of negative effects

16 See Hidalgo and Zunino, 1992; Figueroa and Larraín, 1989, Toro et al., 2003.

ARTICLE: Social Housing and Spatial Segregation in the City of Pucón, Chile: Between Confinement and Integration with Tourist Habitat / Hugo Marcelo Zunino, Rodrigo Hidalgo Dattwyler, Esteban Marquardt Zapata 
dicción, inseguridad, resentimiento, entre otros, cuestiones que detallaremos a continuación.

\section{La Población Cordillera Alto desde la perspectiva del poblador}

\section{DESCRIPCIÓN DE LA MUESTRA}

La Población Cordillera Alto consiste en un complejo de 291 viviendas sociales construidas entre los años 2001 y 2003, que albergan a igual número de familias. Durante la aplicación de la encuesta no se detectaron viviendas desocupadas, lo cual reafirma el carácter residencial del complejo. La muestra consideró a 54 jefes de hogar, lo que representa al $18.5 \%$ del total. En promedio cada grupo familiar está constituido por 3.9 personas, por lo que la muestra consideró al 4.8\% del total estimado de población residente (1135 personas), incluyendo a los menores de edad. Si se excluyen a los menores de edad, se estima que se encuestó entre el $8 \%$ y $10 \%$ de la población, lo cual avala la representatividad de la muestra. El lugar de origen de las personas se distribuye homogéneamente entre familias provenientes del sector rural de la comuna, familias allegadas provenientes del casco consolidado de Pucón y familias provenientes de comunas cercanas, especialmente de Currarehue y Temuco. associated with the location of "Cordillera Alto". Such effects are translated into low levels of residential satisfaction, addiction to drugs, insecurity and resentment, among others.

\section{"Cordillera Alto" from the Perspective of its Dwellers}

\section{DESCRIPTION OF THE SAMPLE}

"Cordillera Alto" is a social housing complex that consists of 291 housing units built between 2001 and 2003. There were no unoccupied houses during the time this survey was conducted. This fact consolidates the residential nature of the complex. Fifty four heads of household, representing 18.5\% of total households were polled. On average, each family is composed of 3.9; this sample surveyed the $4.8 \%$ of the total population of the complex (1,135 people), including minors. If underage people are excluded, $8-10 \%$ of total population was polled, and representativity of the sample is ensured. The place of origin of residents is homogeneously distributed among families that come from rural areas of the district, from the center of the city or from neighboring towns, especially Currarehue and Temuco. 
En cuanto al nivel educacional, el 33\% declaró que había completado su educación media, mientras que el 26\% sólo había completado su educación básica. Un 7\% contaba con educación técnica. Los oficios más practicados por los pobladores son carpintero, albañil, gásfiter y modistas (34\%). En una primera aproximación, nos encontramos con una población de bajos recursos que practican actividades ligadas al sector servicios menores. Un factor que llamó la atención es que más del 37\% de la muestra utiliza su vivienda como taller o cuentan con las herramientas y el espacio para practicar sus oficios. Este elemento sugiere que la vivienda aparte de constituir el lugar donde sus experiencias vitales se desarrollan, constituye para muchos de los residentes su lugar de trabajo, lo cual reafirma el rol esencial que juega la residencia y el barrio como ámbito para articular la vida diaria y variable central en el grado de satisfacción que cada individuo experimenta. El resto de la muestra (63\%) ejerce oficios asalariados, predominando los conductores de taxis colectivos y empleados en servicios públicos. Éstos deben trasladarse diariamente a su lugar de trabajo ubicado en el casco consolidado de Pucón.

\section{SATISFACCIÓN RESIDENCIAL}

Para indagar los niveles de satisfacción, la encuesta consultó a los pobladores a través de una escala del 1 al 10 (Escala de Cantril) sobre el grado de

revista invi № 71 / Mayo 2011 / Volumen N ํㅜ 26: 15-55
Regarding education, 33\% of residents finished secondary school and 26\% of those polled finished primary school, while $7 \%$ have a technical diploma. The most common jobs include carpentry, bricklaying, plumbing and dress making (34\%). As an initial estimation, there is a low income population that engages in activities related to small services. It is interesting to point out that more than 37\% of those polled either use their houses as workshops, or have the tools and space to perform their activities. This element suggests that housing, apart from being the place where vital experiences take place; it is also the workplace of a large number of residents. This fact reinforces the role of the residence and the neighborhood as the elements that link daily life and the main variable with the level of satisfaction. The rest of those polled (63\%) are wage-earners, most of them are taxi drivers or work as public officers. This group has to commute to their workplaces, located in the town center, on a daily basis.

\section{RESIDENTIAL SATISFACTION}

In order to identify the level of satisfaction, this survey used the Cantril Scale, which asked people to rate, from 1 to 10, the level of welfare

ARTICLE: Social Housing and Spatial Segregation in the City of Pucón, Chile: Between Confinement and Integration with Tourist Habitat / Hugo Marcelo Zunino, Rodrigo Hidalgo Dattwyler, Esteban Marquardt Zapata 
bienestar respecto a la vivienda y, en segundo lugar, el barrio/entorno. Antes de aplicar la encuesta se estimó como criterio que los valores iguales o superiores a 6 significarían una percepción favorable, menores o iguales a 4 una percepción desfavorable, y entre 4 y 6 una situación intermedia.

Con respecto a la satisfacción por la residencia, la muestra arrojó un promedio de 6,46, indicador que sugiere una tendencia positiva de percepción sobre la calidad de la vivienda y su función para cumplir con las necesidades vitales. Esta situación se puede explicar por la presencia de un número significativo de trabajadores manuales (obreros, pintores, albañiles) que tienen las condiciones para mejorar la calidad de la vivienda (recordemos que se trata de un Plan de Vivienda Progresiva). Esta inferencia se reafirma con las expresiones de los representantes vecinales, todos los cuales manifestaron que las viviendas entregadas a principios de la década del noventa no eran apropiadas por su pequeño tamaño, especialmente para las familias numerosas. Sin embargo, los pobladores manifestaron que tuvieron la capacidad de mejorar las viviendas de acuerdo a sus necesidades, ya fuese por iniciativa propia o vía ayuda municipal. Expresaron, también, que la construcción de la población les significó un arduo trabajo, lo cual indica que adquirieron un alto compromiso con la mejora de su hábitat. Estos antecedentes nos indican que los pobladores fueron capaces de auto-organizarse y construir las bases in relation to housing and environment. Marks greater or equal to 6 are regarded as positive, marks lower or equal to 4 are regarded as negative and marks between 4 and 6 identify an intermediate situation.

In relation to residential satisfaction, this survey scored 6.46. This suggests that there is a positive perception about the quality of housing and its role to meet vital needs. This situation is explained by the presence of an important number of manual workers (people who work in construction, painters and bricklayers) who are able to improve the quality of the house (as a reminder, this is a Progressive Housing Program). This inference is reinforced by the opinions of community leaders, who stated that the houses provided by the State in the early 90s, due to its small size, did not meet the needs of families, particularly those large in number. However, those surveyed said they were able to improve their houses according to their needs, whether by their own initiative or through municipal support. For these people, neighborhood construction involved hard work; this fact indicates that the dwellers of "Cordillera Alto" were able to organize themselves and laid the basis for the creation of 
para crear un capital social importante y estratégico que les reportó claros beneficios.

En cuanto a la satisfacción respecto al entorno, la muestra alcanzó un promedio de 7,66, indicador que sorprende y sugiere que existe una alta aprobación respecto al medio social y natural que los rodea. Esto se explicaría, en un contexto general, por el agrado de vivir en un entorno privilegiado en cuanto a lo prístino de la naturaleza circundante y a la cercanía que tienen con el centro de la Ciudad de Pucón, enclave turístico con estándares altos para el caso chileno. Las entrevistas permiten corroborar esta inferencia. Para los representantes de la comunidad, el grado de satisfacción es producto de dos situaciones. En primer lugar, en forma consistente con la mejora en las viviendas que los pobladores fueron capaces de realizar, se efectuaron adelantos en el entorno inmediato construyéndose plazas, canchas de fútbol y aceras. En segundo lugar, los dirigentes vecinales mencionan la trascendencia de la relación amena que existe entre los vecinos. Afirman que la mayoría de los vecinos se conoce y se han constituido redes de cooperación y ayuda mutua. Estos elementos apuntan, nuevamente, a la importancia de los vínculos de asociatividad y confianza que la comunidad ha logrado construir a lo largo del tiempo, los cuales pueden englobarse al alero de lo que Putnam (1983) denomina capital social. an important and strategic social capital which brought clear benefits.

As far as satisfaction level with the environment is concerned, the sample scored 7.66; this surprising indicator suggests there is a high approval rate regarding the social and natural environment that surrounds people from "Cordillera Alto". In general terms, this indicator may be explained by the pleasant feeling of living in a privileged environment that enjoys unaltered nature and the closeness to the downtown, a tourist site with high standards for the Chilean case. All the interviews support this inference. For community leaders, the level of satisfaction is the result of two situations. The first one, in line with the improvement of houses, is related to the modification of the immediate environment, which involved the construction of squares, football pitches and sidewalks. The second one refers to the importance of the pleasing relation that exists among neighbors. Those polled expressed that most of neighbors know each other and that cooperation and help networks have been established around this relationship. These elements suggest the importance of the association and confidence links that have been built over time, which, 
Por tanto, el capital social acumulado constituye un factor para explicar los altos índices de satisfacción residencial encontrados. En efecto, la participación en organizaciones es bastante alta (aproximadamente un 30\% de la muestra), declaran integrar en forma activa alguna asociación comunitaria; cifra alta considerando las limitantes estructurales existentes en Chile para una activa participación ciudadana ${ }^{17}$. Los informantes enfatizaron que un amplio número de residentes de la población han formado redes de solidaridad y participación en asuntos que le competen a su bienestar colectivo. El fortalecimiento paulatino de la organización de los ciudadanos se debe al hecho que el periodo de aprobación y construcción del proyecto tardó 9 años, tiempo durante el cual el contacto directo con funcionarios municipales permitió el que los potenciales beneficiarios se conociesen y aprendieran la cultura de la participación ciudadana. De esta forma, la organización vecinal fue asumida e internalizada como una responsabilidad para lograr el éxito de la iniciativa. El método de organización seguido actualmente es la realización de asambleas comunales en las cuales la directiva asume un rol de coordinación, información y canalización de las propuestas surgidas de la asamblea, a su vez que la asamblea tiene la facultad para aprobar o desaprobar las propuestas originadas desde la directiva. Las asambleas se realizan con una frecuencia de 3

17 Ver Zunino, 2006; Zunino e Hidalgo, 2009. in the words of Putnam (1983) are known as social capital.

Therefore, accumulated social capital may explain the high rates of residential satisfaction. In fact, there is a high level of participation in organizations. Thirty percent of respondents are actively engaged in communal associations. This is a high figure, considering the structural restrictions that exist in Chile for active citizen participation $^{17}$. Interviewees stressed that an important number of residents have built solidarity and participation networks in topics related to collective welfare. The fact that the approval and construction process of the project lasted nine years explains the gradual consolidation of citizen organization. During this period, direct contact between dwellers and municipal officers allowed beneficiaries to know each other and learn about citizen participation. In this way, neighborhood organization was regarded and internalized as a responsibility to achieve the success of the initiative. The current organizational method is based on communal assemblies in which the board, aside from coordinating and channeling proposals, also informs about them. These assemblies are held every three months,

17 See Zunino, 2006; Zunino and Hidalgo, 2009 
meses dependiendo de la urgencia de los contenidos en tabla; la asistencia regular es de 30 personas, cifra relativamente baja considerando el número de familias de la población (291). Esto debe ser mirado con atención debido a que, por un lado, es necesario seguir avanzando en aumentar los niveles de participación tanto por parte de la población residente como de los gestores públicos, y, por otro lado, valorar la opinión de los habitantes que intervienen en las convocatorias y sus posibles logros para el bienestar del conjunto de residentes, lo cual puede convertirse en un efecto demostrativo para modificar las pautas de comportamiento en lo que respecta a la participación ciudadana.

En tercer lugar, y concordante con nuestra primera inferencia, los dirigentes vecinales destacan lo positivo que resulta residir en una ciudad-balneario y que los atributos funcionales de la ciudad tienden a aminorar las carencias materiales o los problemas que discutiremos en la siguiente sub-sección. Se colige que los pobladores no se sienten atrapados en un gueto, sino se consideran parte integrante de la ciudad de Pucón. Esto se reafirma considerando que más de la mitad de la población (59\%) se desplaza rutinariamente al centro de la ciudad, ya sea por razones laborales, para comprar enseres básicos o utilizar las áreas verdes localizadas en el centro de la ciudad. depending on the level of urgency of the topics to discuss, and the average attendance is 30 people, a low figure compared to the number of families who live in "Cordillera Alto" (291). This situation should be specially taken into consideration because, on the one hand, there is a need to increase the levels of participation of both the population and public officers, and on the other hand, the opinions and achievements of people who take part in assemblies should be valued for the benefit of neighbors. Thus, behavior guidelines regarding citizen participation may be modified.

The community leaders stress the positive aspects of living in a city like Pucon, and the fact that the functional features of the city tend to minimize material deprivation, as well as the problems that this article seeks to analyze in the following sub-section. It is inferred that dwellers of "Cordillera Alto" do not feel they live in a ghetto, they consider themselves as part of the city of Pucon. This sense of belonging is supported by the fact that more than half of the population (59\%) travel to the downtown on a daily basis, whether to work, buy basic items or enjoy the green areas of the city. 


\section{SITUACIONES-PROBLEMAS}

En base a una escala del 1 al 10 (10 representando un problema gravísimo) se procedió a evaluar los problemas que enfrenta la comunidad en relación a un listado de 15 variables. El principal problema, con una ponderación de 7,29, fue la falta de equipamiento comunitario; la población cuenta sólo con un pequeño parque de juegos en un evidente estado de deterioro y una sala cuna que también se utiliza para otros fines (por ejemplo, como bodega y para asambleas vecinales). Los informantes plantearon que las necesidades más urgentes dicen relación con la construcción de una multicancha bien equipada que permita que los infantes del barrio no tengan que jugar en la calle. Otra situaciónproblema es el excesivo gasto en locomoción que los pobladores efectúan para trasladarse al centro de la Ciudad de Pucón. Según los dirigentes poblacionales, el promedio que cada persona gasta es de más de 20.000 pesos mensuales. Este gasto no está determinado tanto por el costo del pasaje (350 pesos en taxi colectivo) como por la cantidad de veces que los residentes de Cordillera Alto deben trasladarse al centro de la ciudad. Así, la muestra arrojó que el 90\% de los pobladores compra los artículos de primera necesidad preferentemente en el centro. Asociado a lo anterior, más del 50\% de los encuestados declara que sus amistades y familiares más cercanos residen en el centro, aumentando la necesidad de trasladarse diariamente. También les resulta urgente la construcción de una

\section{SITUATIONS-PROBLEMS}

Based on a 1 to 10 scale, being 10 the most severe problem, and considering 15 variables, this survey assessed the difficulties people from "Cordillera Alto" face. The main problem was the lack of communal amenities, which averaged 7.29. The dwellers of "Cordillera Alto" only have a small playground in an evident state of deterioration and a nursery that is used for other purposes (warehouse and neighborhood assemblies). Those interviewed expressed that the most urgent need is the construction of a well-equipped multipurpose pitch that would prevent children from playing on the streets. Another problem situation is the high amount of money dwellers pay to go to downtown Pucón. According to the respondents, the average expenditure for transport is $U \$ 40$ a month. This expenditure is not determined by the cost of a single trip ( $U \$ 0.7$ by travelling on collective taxi), but by the number of times people have to travel to the downtown area of the city. In this way, the $90 \%$ of dwellers purchase essential items preferably in the downtown. In addition, $50 \%$ of those polled said their closest friends and relatives live in the central area, increasing the need for travelling on a daily basis. It is also urgent the construction of a space to hold assemblies. The aspect that also got a high 
sede social que permita la realización de las asambleas de los pobladores. Otro aspecto que recibió una calificación promedio alta $(5,8)$ fue la ausencia de comercio en las cercanías. Los establecimientos existentes en la población ofrecen una limitada variedad de productos, sólo dirigidos a proporcionar artículos de primera necesidad.

Asimismo, el $41 \%$ de los pobladores considera que es una desventaja residir cerca de sectores de altos ingreso; en tanto que para la mayoría (44\%) le es indiferente. Tan sólo el 22\% lo considera una ventaja. Esta indiferencia se asocia con el alto desempleo que se registra entre los pobladores, el cual se estima en un 35\%. Los dirigentes locales entrevistados manifestaron que para la mayoría de los empleos generados por la industria turística requieren haber completado la enseñanza media y contar con estudios técnicos, lo que constituye una clara desventaja para los pobladores en un mercado laboral altamente competitivo. Para los mismos informantes, sólo las personas que se dedican al comercio minorista se ven favorecidas por la llegada de turistas, especialmente durante la época estival.

Finalmente, llamó la atención la negativa percepción que tienen los vecinos en cuanto a la efectividad de los vínculos con la municipalidad. Más del 75\% de la población encuestada declara que no ha sido consultada respecto al desarrollo de su barrio ni respecto a la formulación de los instrumentos de planificación territorial. Similar porcentaje señala disapproval rate (5.8) was the lack of shops in the vicinity of "Cordillera Alto" existent stores offer a limited variety of basic products.

Likewise, $41 \%$ of dwellers considered that living near well off areas is a disadvantage, for the majority of people (44\%), this fact is not of their concern; only $22 \%$ of dwellers regarded it as a disadvantage. This indifference is associated with high unemployment rate (35\%); interviewees expressed that most of the employment generated by the tourist industry requires that applicants have completed secondary education, as well as a certificate. This is a clear disadvantage for people from "La Cordillera" who are looking for a job in a highly competitive labor market. For them, those engaged in retail benefit from tourist activity, especially in summer.

It is worth noting the negative perception of the neighbors regarding the effectiveness of the links with the town council. More than 75\% of those surveyed said they have not been consulted about the development of their neighborhood and the formulation of territorial planning instruments. They also consider that the town council does not pay appropriate attention either to the neighbors or to the neighborhood. It is important to qualify this opinion, community

ARTICLE: Social Housing and Spatial Segregation in the City of Pucón, Chile: Between Confinement and Integration with Tourist Habitat / Hugo Marcelo Zunino, Rodrigo Hidalgo Dattwyler, Esteban Marquardt Zapata 
que considera insuficiente la preocupación de la municipalidad por los vecinos y por el barrio. Es necesario matizar esta apreciación. Los informantes de la junta de vecinos plantearon que si bien no existe interés en participar en la elaboración de instrumentos formales de planificación, sí hay interés por acercarse a la municipalidad para solucionar problemas puntuales. Resaltan que para tener "voz y voto" la iniciativa debe partir de la propia comunidad, asumiendo cabalmente el rol protagónico que les cabe en materia de desarrollo comunitario. Estos líderes perciben que la presencia de la municipalidad en terreno es baja. Para comunicarse con el municipio y plantear sus demandas, los dirigentes envían oficios en forma regular, los que generalmente tienen una respuesta en un plazo prudente. Cuando la respuesta no es satisfactoria, se insiste con un petitorio modificado. Nunca ha sido necesaria una medida de presión. Declaran que las veces que no han sido consideradas sus peticiones es producto del funcionamiento burocrático propio de la Municipalidad y de errores en la distribución de la correspondencia. Son también tajantes en declarar que durante el periodo de la Alcaldesa en ejercicio, las relaciones han mejorado de manera considerable.

Nos encontramos, pues, ante una situación en que existe una muy baja participación en las instancias formales de discusión de los instrumentos de planificación territorial que afectan los niveles más generales (léase planes reguladores o planes de desarro- leaders argued that, although there is no interest in participating in the elaboration of formal planning instruments, there is an interest in speaking with the town council so as to solve specific problems. They stress that, in order to have their say, initiatives should come from the community, with the population assuming the key role regarding communal development. The interviewees consider there is low municipal field presence. When it comes to making demands to the town council, community leaders have to send a letter, which is generally answered within a reasonable length of time. When the reply is not satisfactory, they insist by sending a modified request. There has never been the need for putting pressure on authorities. In addition, respondents said that bureaucracy and misdelivery are the reason of unanswered requests. They are also direct when declaring that relations have substantially improved under the current administration.

Therefore, while there is low participation in formal discussion about the territorial planning instruments that affect general levels (master plans or communal development plans), they have the people and the capacity to influence on determined actions. In this way, despite the acknowledgment of the efforts made by local 
llo comunal), pero sí existe presencia y la suficiente capacidad para incidir en algunas acciones puntuales del gobierno local. Así, a pesar que se reconocen los esfuerzos desplegados por la autoridad local durante los últimos años para mejorar las condiciones de habitabilidad, estas iniciativas se consideran aún insuficientes. Estos antecedentes nos indican que es necesario ampliar y consolidar los canales de participación, establecer instancias formales que aborden situaciones que directamente afectan a la comunidad, y reforzar la interacción cara a cara entre los dirigentes poblacionales y el gobierno local.

\section{Consideraciones Finales}

El caso estudiado arrojó resultados útiles para informar las políticas de vivienda social en el contexto de una ciudad balneario de tamaño pequeño. La evidencia levantada demuestra que no todas las intervenciones del Estado en materia de vivienda social son percibidas de forma negativa y que su resultado finalmente está dado por variables tan relevantes como el entorno donde se materializan y por el grado de compromiso de los beneficiarios con los planes de mejoramiento urbano-residencial. En efecto, bajo ciertas circunstancias, la segregación socio-espacial en un asentamiento menor con vocación turística puede no ser negativa o impulsora de sentimientos adversos respecto al lugar de residencia, como lo han sugerido una gama de investigaciones que han tomado como caso de estudio authorities to improve habitability conditions during the last years, such initiatives are still insufficient. This background suggests the need for enhancing and consolidating participation channels, establishing formal bodies to address situations that affect the community, and reinforcing face to face interaction among community leaders and local authorities.

\section{Concluding Considerations}

This case produced useful results to inform about social housing policies in the context of a small tourist site. Evidence shows that not all State interventions regarding housing are considered negative. The perception of these interventions depends on important variables such as the environment in which the initiatives are materialized and the commitment level of beneficiaries with the urban-residential improvement plans. In effect, under certain circumstances, and unlike a series of research based on large or intermediate cities, sociospatial segregation in a small tourist-oriented settlement may not be negative or the reason for pessimism regarding the place of residence. Despite the fact that socio-spatial segregation in Pucón is stronger than in metropolises or

ARTICLE: Social Housing and Spatial Segregation in the City of Pucón, Chile: Between Confinement and Integration with Tourist Habitat / Hugo Marcelo Zunino, Rodrigo Hidalgo Dattwyler, Esteban Marquardt Zapata 
ciudades grandes o intermedias. A pesar que la situación de segregación socio-espacial en la Ciudad de Pucón es más marcada que en las grandes metrópolis y ciudades intermedias, los altos niveles de satisfacción residencial encontrados están relacionados directamente con dos variables principales: alta valoración del entorno (natural y construido) y la existencia de importantes niveles de capital social.

En relación a la primera variable, un entorno atractivo y que evoque belleza constituye una cualidad que puede ser encontrada en distintos asentamientos menores con vocación turística, en la medida que los residentes tengan la posibilidad de experimentar un contacto inmediato con el medio nourbano que los rodea y utilizar los sectores mejor equipados de la ciudad. En las grandes aglomeraciones los residentes de los complejos de vivienda social permanecen, en muchas ocasiones, enclaustrados dentro de sus barriadas con escasas posibilidades de contactarse con el resto de la ciudad, en general, y con el ambiente natural o rural, en particular. Así, mientras en las ciudades que superan cierto umbral la calidad de las viviendas son de primera importancia para sus residentes dado lo limitado del contacto con lo externo y el largo tiempo que permanecen en ellas; en asentamientos menores la vivienda representa el lugar que media entre el entorno y la individualidad, razón por la cual la calidad de la vivienda pasa a ser compensada, en parte, por los atributos del entorno. En efecto, para los habitantes de la Población Alto intermediate cities, the high levels of residential satisfaction are directly related to two main variables: high appreciation of the environment (natural and constructed) and the presence of considerable levels of social capital.

In relation to the first variable, the environment of minor tourist-oriented settlements may be beautiful and attractive as long as residents have immediate contact with the non-urban space that surrounds them and have access to properly equipped areas of the city. In large cities, residents of social housing remain isolated in their neighborhoods and have few chances to interact with the rest of the city and the natural and rural environment. In this way, while in some cities the quality of houses is of utmost importance for people, given the limited external contact and the long time people stay in them; in minor settlements housing is the place that mediates between environment and individuality, which is why the quality of the house is compensated by the features of the environment. Actually, for the dwellers of "Cordillera Alto", the lush vegetation and proper amenities and structural levels of Pucón are variables that compensate the quality of the housing. 
Cordillera de Pucón, la exuberante naturaleza y los adecuados niveles de equipamiento e infraestructura que posee el casco consolidado de Pucón son variables que vienen a compensar, en parte importante, la calidad de la vivienda.

Este último punto nos lleva a la relevancia del capital social que la comunidad ostenta. A juicio de los vecinos, la posibilidad de obtener una vivienda propia en Pucón hizo que los residentes adquiriesen un fuerte compromiso con el bario y entre ellos. Esto se tradujo en una acción colectiva eficaz que contó con autoridades locales dispuestas a atender las demandas de la comunidad, aunque sin la intensidad y frecuencia demandadas por los pobladores. Estos elementos ayudaron a generar un fuerte sentido de arraigo al lugar y los vecinos optaron por conformar instancias de discusión para mantener la buena convivencia y mejorar su lugar de residencia. Los vínculos de asociatividad se ven también reforzados por la complementariedad de los oficios que practican los pobladores, los cuales permiten el trabajo mancomunado y la mejora de su entorno inmediato.

En base a estas consideraciones, se puede colegir que la radicación de pobladores en ciudades menores con vocación turística puede ser una vía para reorientar la política social en materia de vivienda. No obstante, como este trabajo muestra, existen algunos problemas que es necesario tomar en consideración. Primero, la base económica local debe contar con la necesaria fortaleza para generar em-
This last point reveals the importance of social capital. According to the residents of "Cordillera Alto", the possibility to secure housing in Pucon generated a strong relationship between the neighborhood and them. This relation turned into an effective collective action with local authorities; however, residents consider that authorities did not act as urgent as they expected. These elements contributed to generate a strong sense of belonging. As a result, neighbors created opportunities for discussion so as to maintain social interaction and improve the place of residence. Additionally, the complementarity of residents' activities strengthened associative links, as it combined teamwork and the improvement of the immediate space.

In the light of these considerations, it is inferred that the establishment of people in minor touristoriented cities may be an alternative to redirect social policies in terms of housing. However, this article shows that there are problems that should be taken into consideration. Firstly, the basis of the local economy should be strong enough to generate sustainable employment over the year at a reasonable distance from the place of residence. Job offers are important in tourist sites, presenting significant 
pleo sostenible a lo largo del año, a una distancia razonable del lugar de residencia. Las oportunidades laborales son importantes en los enclaves turísticos, presentando una oferta de empleos significativa en el sector terciario. La clave es mantener la actividad turística relativamente constante a lo largo del año y eso pasa no sólo por los operadores de la actividad sino que también por los gestores del sector público. Segundo, la construcción y mantención del capital social constituye un factor fundamental que las autoridades locales deben ayudar a cultivar. Dado el contingente poblacional involucrado, esto es más factible en asentamientos menores que posean gobiernos locales dinámicos con la voluntad política de involucrarse cara a cara con los pobladores. Tercero, la movilidad de los habitantes de los conjuntos de vivienda social periféricos es un asunto primordial que debe ser atendido por las autoridades, en el entendido que puede ser un problema crítico de su integración social y urbana. La segregación tiene una clara dimensión objetiva (separación entre los sectores sociales), pero los efectos negativos pueden ser atenuados con una buena conectividad y medios de transporte utilizables a un precio razonable. De esta forma la segregación objetiva pasa a relativizarse mediante la facilidad de movimiento que se le ofrece al sujeto. Este es un punto que los residentes en la Población Cordillera consideran crítico y un problema a superar. Considerando que los pobladores de Alto Cordillera poseen claros vínculos funcionales con la Ciu- opportunities in tertiary sector. The key is to keep a relatively constant tourist activity throughout the year; this task does not depend only on people engaged in this activity, but also on public officers. Secondly, the construction and maintenance of social capital is an essential factor that local authorities should help to cultivate. Given the number of people involved, the construction of social capital is more feasible in minor settlements with dynamic local authorities willing to interact with people. Thirdly, daily mobility of dwellers of social housing complexes located in peri-urban areas is a key issue that should be addressed by authorities, since it is a critical problem for urban and social integration. Segregation has a clear objective dimension (separation among social sectors), but its negative effects can be minimized with proper connectivity and more economical means of transport. In this way, objective segregation is lessened through the mobility options the individual is provided with. This is an aspect that people from "Cordillera Alto" regard as critical and as a problem that needs to be solved.

Considering that the dwellers of "Cordillera Alto" have functional links with the City of Pucón, which result in high daily mobility 
dad de Pucón, que se expresan en una alta movilidad entre el lugar de residencia y el centro de la ciudad con el propósito de acceder a sus lugares de trabajo, a una oferta de bienes y servicios diversificados, o para utilizar el equipamiento comunitario existente; distamos mucho de estar en presencia de un "gueto urbano", a la usanza de los encontrados en las grandes ciudades. Esto no quiere decir, en ningún caso, que la situación sea de integración total. Insistimos que la deficiente conectividad y los altos costos de transporte son los problemas apremiantes para la población.

Si bien concordamos con el ideal de una ciudad equitativa y socialmente justa, afirmamos que la segregación no es sinónimo de sentimiento adverso frente a la localización de la vivienda; siempre que se considere la triada trabajo, capital social y movilidad. Para que esto sea posible se requiere de real participación ciudadana, la que en Chile se ha visto mermada por el imperio de la tecnocracia y el debilitamiento de la sociedad civil. Si bien el caso de Pucón puede considerarse un excepcionalismo geográfico, la construcción de complejos de vivienda social en ciudades y territorios con vocación turística constituye una oportunidad para mejorar la calidad de vida de los sectores pobres. between the place of residence and the downtown in order to have access to their workplaces, a supply of diversified goods and services and communal amenities, the "urban ghetto" concept -common in large cities- is far from being applied here. This situation does not mean that there is total integration. Inadequate connectivity and high transport costs are pressing issues for people.

This paper supports the idea of an equitable and socially just city; however, the concept of segregation does not involve pessimism about the localization of the place of residence, provided that work, social capital and mobility are taken into account. In order for this to happen, citizen participation -which has been eroded by technocracy and the weakening of civil society-, is required. While the case of Pucon may be considered as a geographic exception, the construction of social housing complexes in tourist-oriented cities and territories is an opportunity to improve the quality of life in poor areas. 


\section{Bibliografía / Bibliography}

AMÉRIG0, María. Satisfacción residencial. Un análisis psicológico de la vivienda y su entorno. Madrid, España, Alianza Editorial. 1995. 169 p. ISBN 84206-2823-9.

ARRIAGADA, Camilo. Pobreza de América Latina: nuevos escenarios y desafíos de políticas para el hábitat urbano. Santiago, Chile, CEPAL, Serie Medio Ambiente y Desarrollo 27. 2000. 70 p. ISBN 921-321659-9.

AZÓCAR, Gerardo; HENRÍQUEZ, Cristian; VALENZUELA, Claudia y ROMERO, Hugo. Tendencias sociodemográficas y segregación socioespacial en Los Ángeles, Chile. Revista de Geografía Norte Grande, 41: 103-128, diciembre 2008. ISSN 0379-8682.

BRAIN, Isabel y SABATINI, Francisco. Los precios del suelo en alza carcomen el subsidio habitacional, contribuyendo al deterioro en la calidad y localización de la vivienda social. Prourbana, 4: 2-13, junio 2006.

BRAIN, Isabel; CUBILLOS, Gonzalo y SABATINI, Francisco. Integración social urbana en la nueva política habitacional. Temas de agenda pública, 2(7): 1-15, 2007.

CANTRIL, Headley. The pattern of human concerns. New Brunswick, N.J., Rutgers University Press. 1965. $427 \mathrm{p}$.

CASTELLS, Manuel. La cuestión urbana. Madrid, España, Ediciones Siglo XXI. 1996. 528 p. ISBN 978-84-323-0139-1
DE LA PUENTE, Patricio; MUÑOZ, Patricia y TORRES, Emilio. Satisfacción residencial en soluciones habitacionales de radicación y erradicación para sectores pobres de Santiago. EURE, 16(49): 7-22, octubre 1990. ISSN 0250-7161.

DE MATTOS, Carlos. Globalización y metamorfosis urbana en América Latina. Quito, Ecuador, OLACCHI, NDQM, 2010. 374 p.

DE MATTOS, Carlos. Santiago de Chile, globalización y expansión metropolitana: lo que existía sigue existiendo. EURE, 25(76): 29-56, diciembre 1999. ISSN 0250-7161.

DE MATTOS, Carlos. Transformación de las ciudades latinoamericanas: ¿Impactos de la globalización? EURE, 28(85): 5-10, 2002. ISSN 0250-7161.

DÍAZ, Andrea. Manifestaciones de la segregación en la población de viviendas sociales "Plazas de Chivilcan", Temuco. Estudios Sociales, 116: 139-170, 2005. ISSN 0716-0321.

DIEZ, Juan y TORREGROSA, José Ramón. Aplicación de la escala de Cantril en España: Resultados de un estudio preliminar. Revista española de la opinión pública, 10: 77-100, 1967. ISSN 0034-9429

DIRECCIÓN DE OBRAS MUNICIPALES. Archivo. Pucón, Chile, Municipalidad de Pucón, 2010.

FIGUEROA, Roberto y LARRAÍN, Patricio. Renovación urbana y satisfacción residencial en la remodelación San Borja. Revista de Geografía Norte Grande, 16: 75-86, 1989. ISSN 0379-8682.

FOUCAULT, Michael. Of other spaces, Diacritics: 16(1): 22-27, 1986. ISSN 0300-7162. 
GARÍN, Alan; SALVO, Sonia y ARANEDA, Gonzalo. Segregación residencial y políticas de vivienda en Temuco. 1992-2002. Revista de Geografía Norte Grande, 44: 113-128, diciembre 2009. ISSN 0379-8682.

GONZÁLEZ, Rodrigo; OTERO, Adriana; NAKAYAMA, Lía y MARIONI, Susana. Las movilidades del turismo y las migraciones de amenidad: problemáticas y contradicciones en el desarrollo de centros turísticos de montaña. Revista de Geografía Norte Grande, 44: 75-92, diciembre 2009. ISSN 0379-8682.

HIDALG0, Rodrigo. ¿Se acabó el suelo en la gran ciudad? Las nuevas periferias metropolitanas de la vivienda social en Santiago de Chile. EURE, 33(98): 57-75, marzo 2007. ISSN 0717-6236.

HIDALG0, Rodrigo y ZUNINO, Hugo. Negocios inmobiliarios en centros turísticos de montaña y nuevos modos de vida: el papel de los migrantes de amenidad en la comuna de Pucón, IX Región de la Araucanía, Chile. Estudios y Perspectivas en Turismo, 20: 307-326, marzo 2011.

HIDALG0, Rodrigo y ZUNINO, Hugo. Consideraciones preliminares para un proyecto de renovación urbana en un área central de la ciudad de Santiago, Chile. Revista de Geografía de la Universidad Estadual Paulista, 11: 31-45, 1992. ISSN 0101-9457.

ILUSTRE MUNICIPALIDAD DE PUCÓN. Actualización Plan Regulador Comunal de Pucón. [En línea]. 2006. [Fecha de consulta: 25 de julio de 2010] Disponible en: http://www.municipalidadpucon. cl/para\%20descarga/Plan\%20regulador/Inventario/capituloll.pdf.

54 revista invi № 71 / Mayo 2011 / Volumen № 26: 15-55
INSTITUTO NACIONAL DE ESTADÍSTICAS (INE). XVII Censo Nacional de Población y Vivienda 2002. Santiago, Chile, 2002.

LINARES, Santiago. y LAN, Diana. Análisis multidimensional de la segregación socioespacial en Tandil (Argentina), aplicando SIG. Investigaciones Geográficas, 44: 149-166, 2007. ISSN 0213-4691.

OTERO, Adriana; NAKAYAMA, Lía; MARIONI, Susana; GALLEGO, Elisa; LONAC, Alicia; DIMITRIU, Andrés; GONZÁLEZ, Rodrigo y HOSID, Claudia. Amenity migration in the Patagonian mountain community of San Martín de los Andes, Neuquén, Argentina. En: MOSS, L. (Ed.). The Amenity Migrants: Seeking and Sustaining Mountains and their Cultures. Santa Fe, USA: Consultant \& Educator. 2006. P. 200-213. ISBN 978-0851990842.

PUTNAM, Robert. Making democracy work. Civic traditions in modern Italy. Princeton, USA, Princeton University Press. 1993. 258 p.

RODRÍGUEZ, Alfredo y SUGRANYES, Ana. El problema de vivienda de los "con techo". EURE, 30(91): 53-65, 2004. ISSN 0717-6236.

RODRíGUEZ, Alfredo y SUGRANYES, Ana (Eds.) Los con techo. Un desafío para la política de vivienda social. Santiago, Chile, SUR. 2005. 265 p.

ROJO, F.; PÉREZ, G.; FERNÁNDEZ, G.; FERNÁNDEZ, E. y ROJO, J. Ageing in place: predictors of the residential satisfaction of elderly Social Indicators Research, 54(2): 173-208, 2001. ISSN 1573-0921.

ARTICLE: Social Housing and Spatial Segregation in the City of Pucón, Chile: Between Confinement and Integration with Tourist Habitat / Hugo Marcelo Zunino, Rodrigo Hidalgo Dattwyler, Esteban Marquardt Zapata 
TOLEDO, Ximena; ROMERO, Hugo y GARín, Alan. Segregación socioespacial en la Comuna de Temuco. Espacio y Desarrollo, 12: 103-122, 2000. ISSN 1016-9148.

TORO, Alejando; JIRÓN, Paola y GOLDSACK, Luis. Análisis e incorporación de factores de calidad habitacional en el diseño de las viviendas sociales en Chile. Propuesta metodológica para un enfoque integral de la calidad residencial. Boletín del Instituto de la Vivienda, (46): 9-21, 2003. ISSN 0716-5668.

ZUNINO, Hugo Marcelo. Power relations in urban decision making: neoliberalism, techno-politicians, and authoritarian redevelopment in Santiago. Urban Studies, 43(1): 1825-1846, 2006. ISSN 1360063X.

ZUNINO, Hugo Marcelo e HIDALGO, Rodrigo. Studying the spatial and socioeconomic effects of housing policies in neoliberal Chile: The Case of Valparaíso. Urban Geography, 30(5): 514-542, 2009. ISSN 0272-3638.

ZUNINO, Hugo Marcelo e HIDALGO, Rodrigo. En busca de la utopía verde: migrantes de amenidad en la comuna de Pucón, IX Región de la Araucanía, Chile. XI Coloquio Internacional de Geocrítica: La planificación territorial y el urbanismo desde el diálogo y la participación. Buenos Aires, Argentina, Universidad de Buenos Aires. 2010. [Fecha de consulta: 1 de julio de 2010] Disponible en: http://eventos.filo.uba.ar/index.php/geocritica/2010/paper/viewFile/386/169. 